Letters to the Editor

\title{
1-(Ethylthio)-3-(dihalo-1,3,5-triazinyl)-2-n-propylisoindole as Fluorescent Labeling Reagent for Estrogens
}

\author{
Hiroyuki FuJino and Shujiro Goya \\ Faculty of Pharmaceutical Sciences, Kumamoto University, Kumamoto 862, Japan
}

\begin{abstract}
Keywords 1-(Ethylthio)-3-(dihalo-1,3,5-triazinyl)-2-n-propylisoindole, fluorescent labeling reagent, estrogen, high performance liquid chromatography
\end{abstract}

Recently we reported that 1-(dichloro-1,3,5-triazinyl)2-methylisoindole (DTMI) was useful as a fluorescent labeling reagent for estrogens. ${ }^{1}$ This paper describes the preparation of 1-(ethylthio)-3-(dichloro-1,3,5-triazinyl)-2-n-propylisoindole (ECPI) and 1-(ethylthio)-3(difluoro-1,3,5-triazinyl)-2-n-propylisoindole (EFPI) and their applicabilities to fluorescent labeling of estrogens in high performance liquid chromatography (HPLC).

\section{Experimental}

\section{Instrumental conditions}

Proton and fluorine nuclear magnetic resonance $\left({ }^{1} \mathrm{H}-\right.$ and ${ }^{19} \mathrm{~F}-\mathrm{NMR}$ ) spectra were recorded on a JNMGX400 spectrometer at $400 \mathrm{MHz}$ for ${ }^{1} \mathrm{H}$ and at $376 \mathrm{MHz}$ for ${ }^{19} \mathrm{~F}$ (JEOL Ltd., Tokyo). Chemical shifts were reported in parts per million relative to tetramethylsilane $(\delta 0.00)$ for ${ }^{1} \mathrm{H}-\mathrm{NMR}$ and benzotrifluoride ( $\phi 67.75$ ) for ${ }^{19} \mathrm{~F}-\mathrm{NMR}$ as an internal standard, respectively. Mass spectra were taken with a JMSDX303HF spectrometer (JEOL Ltd., Tokyo). A 655A11 high performance liquid chromatograph (Hitachi Ltd., Tokyo) was used with a F-1000 fluorescence detector (Hitachi Ltd., Tokyo) operating at Ex $415 \mathrm{~nm}$ and $\mathrm{Em} 445 \mathrm{~nm}$. The column was stainless steel (250×4.6 mm i.d.) packed with a TSKgel ODS-120 A (particle size $5 \mu \mathrm{m}$, TOSOH, Tokyo). Methanol-water (15:1) was used as a mobile phase at a flow rate of $1.0 \mathrm{ml} / \mathrm{min}$ at room temperature.

\section{Synthesis of ECPI}

$o$-Phthalaldehyde $(268 \mathrm{mg})$, ethanethiol $(150 \mu \mathrm{l})$, and $n$-propylamine $(165 \mu \mathrm{l})$ were mixed in the stated order in $10 \mathrm{ml}$ of anhydrous ether at room temperature; then the mixture was cooled in ice-water. To this solution, an ethereal solution $(20 \mathrm{ml})$ of cyanuric chloride (368 mg) was added drop by drop with stirring. After stirred for $1 \mathrm{~min}$, the solvent was removed under reduced pressure. The red-black oily residue was dissolved in $10 \mathrm{ml}$ of acetone and applied to preparative silica gel thin-layer plates using benzene as eluent. The band of ECPI was extracted with acetone and evaporated to dryness in vacuo. The residue was purified by precipitation from a concentrated acetone solution by the dropwise addition of water, followed by drying under reduced pressure to yield $120 \mathrm{mg}$ as orange needles (mp $108^{\circ}-109^{\circ} \mathrm{C}$ ). Anal. Calcd. for $\mathrm{C}_{16} \mathrm{H}_{16}$ $\mathrm{Cl}_{2} \mathrm{~N}_{4} \mathrm{~S}: 52.32 \% \mathrm{C}, 4.39 \% \mathrm{H}, 15.25 \% \mathrm{~N}$; found: $52.20 \%$ C, $4.47 \% \mathrm{H}, 15.15 \% \mathrm{~N}$. MS $m / z: 366\left(\mathrm{M}^{+}\right)$. ${ }^{1} \mathrm{H}-\mathrm{NMR}$ $\left(\mathrm{CDCl}_{3}\right) \delta: 1.05\left(3 \mathrm{H}, \mathrm{t}, \mathrm{C}_{14}-\mathrm{H}\right), 1.24\left(3 \mathrm{H}, \mathrm{t}, \mathrm{C}_{11}-\mathrm{H}\right), 1.81$ $\left(2 \mathrm{H}, \mathrm{tq}, \mathrm{C}_{13}-\mathrm{H}\right), 2.92\left(2 \mathrm{H}, \mathrm{q}, \mathrm{C}_{10}-\mathrm{H}\right), 5.00-5.10(2 \mathrm{H}, \mathrm{m}$, $\left.\mathrm{C}_{12}-\mathrm{H}\right), 7.29\left(1 \mathrm{H}, \mathrm{t}, \mathrm{C}_{5}-\mathrm{H}\right), 7.44\left(1 \mathrm{H}, \mathrm{t}, \mathrm{C}_{6}-\mathrm{H}\right), 7.84$ (1 H, d, $\left.\mathrm{C}_{4}-\mathrm{H}\right), 8.71$ (1H, d, $\left.\mathrm{C}_{7}-\mathrm{H}\right)$.

\section{Synthesis of EFPI}

The starting material was cyanuric fluoride and the method was the same as for ECPI. EFPI $(100 \mathrm{mg})$ was obtained as orange needles (mp $\left.105^{\circ}-106^{\circ} \mathrm{C}\right)$. Anal. Calcd. for $\mathrm{C}_{16} \mathrm{H}_{16} \mathrm{~F}_{2} \mathrm{~N}_{4} \mathrm{~S}: 57.47 \% \mathrm{C}, 4.82 \% \mathrm{H}, 16.75 \% \mathrm{~N}$; found: $57.14 \% \mathrm{C}, 4.68 \% \mathrm{H}, 16.53 \% \mathrm{~N}$. MS $\mathrm{m} / z$ : 334 $\left(\mathrm{M}^{+}\right) . \quad{ }^{1} \mathrm{H}-\mathrm{NMR}\left(\mathrm{CDCl}_{3}\right) \delta: 1.04\left(3 \mathrm{H}, \mathrm{t}, \mathrm{C}_{14}-\mathrm{H}\right), 1.24$ $\left(3 \mathrm{H}, \mathrm{t}, \mathrm{C}_{11}-\mathrm{H}\right), 1.82\left(2 \mathrm{H}, \mathrm{tq}, \mathrm{C}_{13}-\mathrm{H}\right), 2.93\left(2 \mathrm{H}, \mathrm{q}, \mathrm{C}_{10^{-}}\right.$ H), $5.03-5.14$ (2H, m, $\left.\mathrm{C}_{12}-\mathrm{H}\right), 7.29\left(1 \mathrm{H}, \mathrm{t}, \mathrm{C}_{5}-\mathrm{H}\right), 7.45$ $\left(1 \mathrm{H}, \mathrm{t}, \mathrm{C}_{6}-\mathrm{H}\right), 7.85\left(1 \mathrm{H}, \mathrm{d}, \mathrm{C}_{4}-\mathrm{H}\right), 8.76\left(1 \mathrm{H}, \mathrm{d}, \mathrm{C}_{7}-\mathrm{H}\right)$. ${ }^{19} \mathrm{~F}-\mathrm{NMR}\left(\mathrm{CDCl}_{3}\right) \phi: 93.32(\mathrm{~s})$.

\section{Derivatization procedure}

To an acetone solution of estrogens (each 25 pmol, $20 \mu \mathrm{l})$ was added ECPI or EFPI in acetone $(3 \mathrm{mM}$, $20 \mu \mathrm{l}$ ), followed by $10 \mu \mathrm{l}$ of $50 \mathrm{mM}$ aqueous $\mathrm{NaOH}$ for ECPI or $10 \mathrm{mM}$ aqueous $\mathrm{NaOH}$ for EFPI, respectively. After being kept for $5 \mathrm{~s}$ at room temperature, $10 \mu \mathrm{l}$ of $174 \mathrm{mM}$ acetic acid for ECPI or $17.4 \mathrm{mM}$ acetic acid for EFPI was added; the components were mixed thoroughly. Then $10 \mu \mathrm{l}$ of the final solution was injected into the HPLC apparatus.

\section{Results and Discussion}

We have studied the DTMI analogues which were 


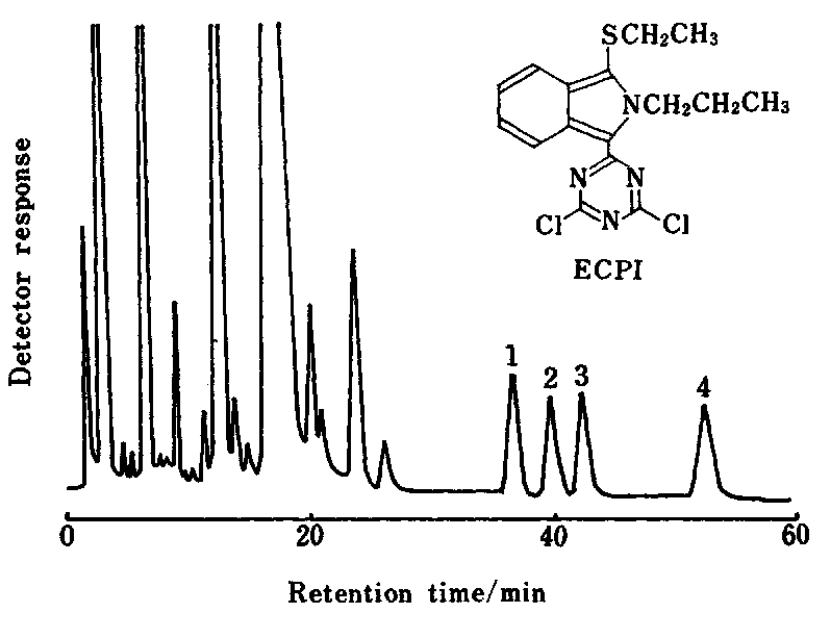

Fig. 1 Chromatogram of estrogens labeled with ECPI. Peaks: 1, ethinylestradiol; 2, 17 $\alpha$-estradiol; 3 , estrone; $4,17 \beta$-estradiol.

more reactive and sensitive than DTMI. The insertion of triazinyl groups to 1-(ethylthio)-2-n-propylisoindole ${ }^{2,3}$ afforded ECPI and EFPI. EFPI was more stable than DTMI and could be used for 1 week in acetone solution when protected from light at room temperature. ECPI and EFPI readily reacted with the phenolic hydroxyl group of estrogens in alkaline medium at room temperature to give the corresponding fluorescent derivatives. The structures of the derivatives were confirmed by fast atom bombardment mass spectrometry. The reactivities of the two reagents were investigated with estrone as a model compound. Based upon our preliminary examinations, reaction time of $5 \mathrm{~s}$ at $25^{\circ} \mathrm{C}$, a 1200 -fold excess of ECPI or EFPI for estrone, and $50 \mathrm{mM} \mathrm{NaOH}$ for ECPI or $10 \mathrm{mM} \mathrm{NaOH}$ for EFPI were employed throughout the study. The alkaline reaction mixture was neutralized by the addition of $174 \mathrm{mM}$ acetic acid for ECPI or $17.4 \mathrm{mM}$ acetic acid for EFPI to protect the column. The product in the final solution was stable for $48 \mathrm{~h}$. The detection

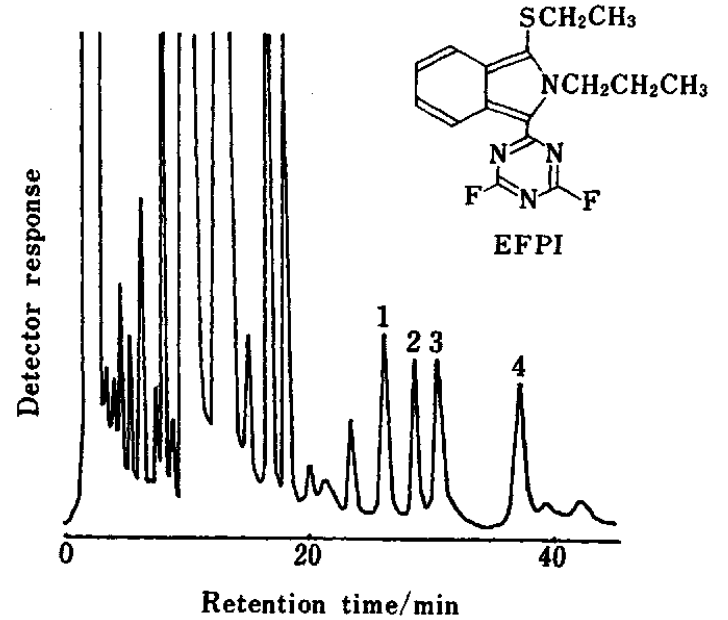

Fig. 2 Chromatogram of estrogens labeled with ECPI. Peaks: 1, estrone; 2, ethinylestradiol; 3, $17 \alpha$-estradiol; $4,7 \beta$-estradiol.

limit (signal $/$ noise $=2$ ) for estrone was $1.1 \mathrm{pmol}$ with ECPI and $270 \mathrm{fmol}$ with EFPI per injection. The detection sensitivity of EFPI was about 10 times higher than that with DTMI. ${ }^{1}$ Figures 1 and 2 show the separation profiles of $25 \mathrm{pmol}$ each of the derivatized mixture of estrogens with ECPI amd EFPI, respectively. Further studies on the utilities of ECPI and EFPI for clinical applications are in progress.

\section{References}

1. H. Fujino and S. Goya, Yakugaku Zasshi, 108, 665 (1988).

2. S. S. Simons, Jr., and D. F. Johnson, J. Am. Chem. Soc., 98, 7098 (1976).

3. S. S. Simons, Jr., H. L. Ammon, R. Doherty and D. F. Johnson, J. Org. Chem., 46, 4739 (1981).

(Received October 26, 1988) (Accepted November 29, 1988) 